\title{
New yellow head virus genotype (YHV7) in giant tiger shrimp Penaeus monodon indigenous to northern Australia
}

\author{
Peter G. Mohr ${ }^{1, *}$, Nicholas J. G. Moody ${ }^{1}$, John Hoad ${ }^{1}$, Lynette M. Williams ${ }^{1}$, \\ Rachel O. Bowater ${ }^{2}$, David M. Cummins ${ }^{1}$, Jeff A. Cowley ${ }^{3}$, Mark StJ. Crane ${ }^{1}$ \\ ${ }^{1}$ CSIRO Australian Animal Health Laboratory, Geelong, VIC 3220, Australia \\ ${ }^{2}$ Department of Agriculture, Fisheries and Forestry, Biosecurity Queensland, Townsville, QLD 4810, Australia \\ ${ }^{3}$ CSIRO Agriculture Flagship, Queensland Bioscience Precinct, St. Lucia, QLD 4067, Australia
}

\begin{abstract}
In 2012, giant tiger shrimp Penaeus monodon originally sourced from Joseph Bonaparte Gulf in northern Australia were examined in an attempt to identify the cause of elevated mortalities among broodstock at a Queensland hatchery. Nucleic acid extracted from ethanolfixed gills of 3 individual shrimp tested positive using the OIE YHV Protocol 2 RT-PCR designed to differentiate yellow head virus (YHV1) from gill-associated virus (GAV, synonymous with YHV2) and the OIE YHV Protocol 3 RT-nested PCR designed for consensus detection of YHV genotypes. Sequence analysis of the $794 \mathrm{bp}$ (Protocol 2) and $359 \mathrm{bp}$ (Protocol 3) amplicons from 2 distinct regions of ORF1b showed that the yellow-head-complex virus detected was novel when compared with Genotypes 1 to 6 . Nucleotide identity on the Protocol 2 and Protocol 3 ORF1b sequences was highest with the highly pathogenic YHV1 genotype (81 and 87\%, respectively) that emerged in P. monodon in Thailand and lower with GAV (78 and $82 \%$, respectively) that is enzootic to $P$. monodon inhabiting eastern Australia. Comparison of a longer (725 bp) ORF1b sequence, spanning the Protocol 3 region and amplified using a modified YH30/31 RT-nPCR, provided further phylogenetic evidence for the virus being distinct from the 6 described YHV genotypes. The virus represents a unique seventh YHV genotype (YHV7). Despite the mortalities observed, the role of YHV7 remains unknown.
\end{abstract}

KEY WORDS: Yellow head virus · Genotype $7 \cdot$ Penaeus monodon · Australia - Resale or republication not permitted without written consent of the publisher

\section{INTRODUCTION}

Yellow head virus (YHV) emerged in the early 1990s as the cause of mass mortalities of giant tiger shrimp Penaeus monodon farmed in Thailand (Chantanachookin et al. 1993). In Thailand YHV continues to cause farm production losses and has become established as a pathogen in farmed Pacific white shrimp P. vannamei (Senapin et al. 2010). In addition, YHV has been reported from most shrimp farming regions where $P$. monodon occur and has also emerged in Pacific blue shrimp P. stylirostris in the Gulf of California (Castro-Longoria et al. 2008). While YHV is exotic to Australia, a closely related genotypic variant, gill-associated virus (GAV, syn- onymous with YHV2), was discovered not long after the discovery of YHV (Spann et al. 1997, Cowley et al. 1999). GAV is enzootic and can occur at high prevalence in wild and farmed $P$. monodon in eastern Australia and can cause disease on farms (Cowley et al. 2000, Munro et al. 2011). GAV has also been detected in shrimp farmed in Vietnam and Thailand (Wijegoonawardane et al. 2008a).

GAV is designated as the type species of the genus Okavirus, family Roniviridae in the order Nidovirales (Walker et al. 2005). ORF1b sequence comparisons of yellow head-related viruses detected in P. monodon collected across the Indo-Pacific region between 1997 and 2004 identified 6 distinct genotypes (Wijegoonawardane et al. 2008a). Except for YHV (YHV1) 
and GAV (YHV2), genotypes YHV3 to YHV6 were detected in healthy P. monodon. The latter genotypes were described based on both the ORF1b phylogeny and their geographic location (e.g. YHV3 in Thailand and Vietnam, YHV4 in India, YHV5 in Malaysia, Thailand and the Philippines, and YHV6 in Mozambique). YHV1 types occurring in Thailand have also been assigned to subtypes YHV1a and YHV1b based on the latter possessing a 54 amino acid deletion in the $\mathrm{N}$-terminal region of the ORF3 coding sequence, although both genotypes retain similar virulence in P. vannamei (Sittidilokratna et al. 2009, Senapin et al. 2010).

P. monodon is the primary shrimp species farmed in Australia, and, in recent years, substantial progress has been made in the domestication and selective breeding of this species (Preston et al. 2010). However, most hatcheries supplying P. monodon seedstock for aquaculture remain reliant on wildcaught broodstock. Until recently, the majority of wild broodstocks were sourced from the CairnsInnisfail region of North Queensland. However, the high prevalence of GAV in the region has led to hatcheries sourcing broodstock from increasingly remote locations in northern Australia.

In 2012, a Queensland hatchery reported elevated mortalities in $P$. monodon broodstock sourced from Joseph Bonaparte Gulf in northern Australia. This report describes the molecular assays which led to the identification of a novel yellow-head-complex virus in samples from diseased animals. The role of the novel yellow-head-complex virus in the disease episode is unknown.

\section{MATERIALS AND METHODS}

\section{Shrimp sample collection and processing}

In November 2012, a batch of 414 wild Penaeus monodon broodstock were caught by net and trawl in Joseph Bonaparte Gulf in northern Australia and transported to a commercial hatchery in North Queensland. Upon arrival, the shrimp were bathed in a prophylactic solution containing formalin and povidine-iodine before being placed into concrete raceways. Mortalities began to occur from Day 1 poststocking, increasing progressively to $81.4 \%$ by Day 12 .

Due to the high mortality rate, tissues for histology, bacteriology and PCR were sampled from 3 moribund broodstocks by the Queensland Department of Agriculture, Fisheries and Forestry (QDAFF). Cephalothoraxes were fixed in Davidson's AFA fixative, processed for histology, and tissue sections were stained with either haematoxylin \& eosin or Brown \& Brenn's Gram stain using standard procedures (Lightner 1996). Preliminary analysis suggested the presence of a yellow-head-complex virus.

Three samples of gill and epidermis, fixed in ethanol, were submitted to the CSIRO AAHL Fish Diseases Laboratory, Geelong, Victoria, for confirmatory testing. Samples were homogenised in $600 \mu \mathrm{l}$ AVL buffer in MagNA Lyser green bead tubes using the MagNA Lyser (Roche) and clarified by centrifugation at $10000 \times g$ for $5 \mathrm{~min}$. RNA was extracted from $140 \mu \mathrm{l}$ using the QIAmp Viral RNA Mini Kit (QIAGEN) and eluted in a final volume of $60 \mu \mathrm{l}$ with AVE buffer.

\section{PCR tests}

The samples were initially tested using 3 PCR protocols as described in OIE (2014). The OIE YHV Protocol 2 multiplex reverse transcriptase-nested PCR (RT-nPCR) was performed as 2 separate RT-nPCR assays, one specific for GAV and the other for YHV1. An additional RT-nPCR, using the YH30-F2/R2 RT-PCR and YH31-F2/R2 nPCR primers targeting ORF1b (Wijegoonawardane et al. 2008a) encompassing the OIE YHV Protocol 3 RT-PCR region was also used, with modified primers. The 4 modified YH30m/ YH31m RT-nPCR primers had additional redundancy to attempt the amplification of more divergent yellowhead-complex viruses. Primer sequences and thermal cycling conditions used in each PCR test are detailed in Table 1.

For each RT-PCR, $2 \mu \mathrm{l}$ RNA was added to $23 \mu \mathrm{l}$ reaction mixture containing $12.5 \mu \mathrm{l} 2 \times$ reaction mix, $1 \mu \mathrm{l}$ Superscript@ III RT/Platinum @ Taq mix (Invitrogen), $180 \mathrm{nM}$ of each primer and molecular grade water. For each nPCR, $2 \mu \mathrm{l}$ of the RT-PCR was added to $23 \mu \mathrm{l}$ reaction mix containing $12.5 \mu \mathrm{l}$ HotStarTaq master mix (QIAGEN), $360 \mathrm{nM}$ of each primer and molecular grade water. Positive control nucleic acids from YHV1 and GAV were included in each assay. To confirm the success of the extraction and the absence of PCR inhibitors, each sample was tested using the OIE Decapod PCR targeted to shrimp genomic 18S rRNA (Lo et al. 1996).

\section{DNA sequencing and phylogenetic analyses}

Amplicons resolved in SYBR safe-stained 1.5\% agarose gels were excised and purified with the 
QIAquick gel extraction kit (QIAGEN). Each amplicon was Sanger-sequenced using both the forward and reverse primers and the BigDye ${ }^{\circledR}$ Terminator v3.1 Cycle Sequencing reagent (Life Technologies) by direct-product sequencing. Geneious software (Biomatters) was used to generate consensus sequences, multiple sequence alignments and calculate pair-wise distances. Phylogenetic analysis using the neighbor-joining method with a bootstrap consensus tree being inferred from 10000 replicates was conducted using MEGA5.1 software (Tamura et al. 2011).

\section{RESULTS}

\section{Histology and bacteriology}

In all 3 moribund broodstocks that were examined by histology, lesions included neuropathy of the eye, antennae, ventral nerve cord and segmental ganglia of pereiopods and retinitis (data not shown). The lesions included lymphoid organ spheroids indicative of virus infection and were typical of those described by Callinan et al. (2003) for acute GAV infection. Bacterial culture of haemolymph produced

Table 1. Molecular assays, primers and thermal cycling conditions used in this study. ORF1b region numbering based on the yellow head virus 1 (YHV1) genome, EU487200.1

\begin{tabular}{|c|c|c|c|c|c|c|c|c|}
\hline PCR Assay & Primer & Sequence $\left(5^{\prime}-3^{\prime}\right)$ & \multicolumn{3}{|c|}{ Thermal cycling conditions } & $\begin{array}{l}\text { Amplicon } \\
\text { size (bp) }\end{array}$ & $\begin{array}{l}\text { ORF1b } \\
\text { region }\end{array}$ & Reference \\
\hline \multicolumn{9}{|c|}{ OIE YHV Protocol 1} \\
\hline \multirow[t]{5}{*}{ RT-PCR } & $\begin{array}{l}10 \mathrm{~F} \\
144 \mathrm{R}\end{array}$ & $\begin{array}{l}\text { CCGCTAATTTCAAAAACTACG } \\
\text { AAGGTGTTATGTCGAGGAAGT }\end{array}$ & $1 \times$ & $\begin{array}{l}50^{\circ} \mathrm{C} \\
94^{\circ} \mathrm{C}\end{array}$ & $\begin{array}{l}30 \min \\
2 \min \end{array}$ & \multirow[t]{5}{*}{135} & \multirow[t]{5}{*}{ 13830-13964 } & \multirow[t]{5}{*}{$\begin{array}{l}\text { Wongteerasupaya } \\
\text { et al. (1997) }\end{array}$} \\
\hline & \multirow{4}{*}{$144 \mathrm{R}$} & & \multirow[t]{4}{*}{$\overline{40 \times}$} & $94^{\circ} \mathrm{C}$ & $30 \mathrm{~s}$ & & & \\
\hline & & & & $58^{\circ} \mathrm{C}$ & $45 \mathrm{~s}$ & & & \\
\hline & & & & $68^{\circ} \mathrm{C}$ & $45 \mathrm{~s}$ & & & \\
\hline & & & & $68^{\circ} \mathrm{C}$ & $7 \mathrm{~min}$ & & & \\
\hline \multicolumn{9}{|c|}{ OIE YHV Protocol 2} \\
\hline RT-PCR & $\begin{array}{l}\text { GY1 } \\
\text { GY4 }\end{array}$ & $\begin{array}{l}\text { GACATCACTCCAGACAACATCTG } \\
\text { GTGAAGTCCATGTGTGTGAGACG }\end{array}$ & $1 \times$ & $\begin{array}{l}50^{\circ} \mathrm{C} \\
95^{\circ} \mathrm{C}\end{array}$ & $\begin{array}{l}30 \min \\
2 \min \end{array}$ & \multirow[t]{5}{*}{794} & \multirow[t]{5}{*}{$12848-13641$} & \multirow[t]{5}{*}{ Cowley et al. (2004) } \\
\hline & & & $35 \times$ & $95^{\circ} \mathrm{C}$ & $30 \mathrm{~s}$ & & & \\
\hline & & & & $66^{\circ} \mathrm{C}$ & $30 \mathrm{~s}$ & & & \\
\hline & & & & $68^{\circ} \mathrm{C}$ & $45 \mathrm{~s}$ & & & \\
\hline & & & $1 \times$ & $68^{\circ} \mathrm{C}$ & $7 \mathrm{~min}$ & & & \\
\hline \multirow[t]{5}{*}{ GAV nPCR } & GY2 & CATCTGTCCAGAAGGCGTCTATGA & $1 \times$ & $95^{\circ} \mathrm{C}$ & $15 \mathrm{~min}$ & \multirow[t]{5}{*}{406} & \multirow[t]{5}{*}{$12865-13270$} & Cowley et al. (2004) \\
\hline & G6 & GTAGTAGAGACGAGTGACACCTAT & $35 \times$ & $95^{\circ} \mathrm{C}$ & $30 \mathrm{~s}$ & & & \\
\hline & & & & $66^{\circ} \mathrm{C}$ & $30 \mathrm{~s}$ & & & \\
\hline & & & & $72^{\circ} \mathrm{C}$ & $45 \mathrm{~s}$ & & & \\
\hline & & & $1 \times$ & $72^{\circ} \mathrm{C}$ & $7 \min$ & & & \\
\hline YHV1 nPCR & GY2 & As above & As & per OIE & $\mathrm{YHV}$ & 277 & $12865-13141$ & Cowley et al. (2004) \\
\hline OIE YHV Pro & tocol 3 & ACGCICIGIGACAAGCAIGAAGII & Protoc & $012 G A$ & nPCR & & & \\
\hline RT-PCR & YC-F1a & ATCGTCGTCAGCTACCGCAATACTGC & $1 \times$ & $50^{\circ} \mathrm{C}$ & $55 \mathrm{~min}$ & 359 & $17441-17799$ & Wijegoonawardane \\
\hline & YC-F1b & ATCGTCGTCAGYTAYCGTAACACCGC & & $95^{\circ} \mathrm{C}$ & $2 \min$ & & & et al. (2008b) \\
\hline & YC-R1a & TCTTCRCGTGTGAACACYTTCTTRGC & $35 \times$ & $94^{\circ} \mathrm{C}$ & $45 \mathrm{~s}$ & & & \\
\hline & YC-R1b & TCTGCGTGGGTGAACACCTTCTTGGC & & $60^{\circ} \mathrm{C}$ & $45 \mathrm{~s}$ & & & \\
\hline & & & & $68^{\circ} \mathrm{C}$ & $45 \mathrm{~s}$ & & & \\
\hline & & & $1 \times$ & $68^{\circ} \mathrm{C}$ & $7 \mathrm{~min}$ & & & \\
\hline $\mathrm{nPCR}$ & YC-F2a & CGCTTCCAATGTATCTGYATGCACCA & $1 \times$ & $95^{\circ} \mathrm{C}$ & $15 \mathrm{~min}$ & 147 & $17513-17659$ & Wijegoonawardane \\
\hline & YC-F2b & CGCTTYCARTGTATCTGCATGCACCA & $35 \times$ & $95^{\circ} \mathrm{C}$ & $30 \mathrm{~s}$ & & & et al. (2008b) \\
\hline & YC-R2a & RTCDGTGTACATGTTTGAGAGTTTGTT & & $66^{\circ} \mathrm{C}$ & $30 \mathrm{~s}$ & & & \\
\hline & $\mathrm{YC}-\mathrm{R} 2 \mathrm{~b}$ & GTCAGTGTACATATTGGAGAGTTTRTT & & $72^{\circ} \mathrm{C}$ & $45 \mathrm{~s}$ & & & \\
\hline & & & $1 \times$ & $72^{\circ} \mathrm{C}$ & $7 \mathrm{~min}$ & & & \\
\hline YH30m/31m & & & & & & & & \\
\hline RT-PCR & YH30-F1m & TACCAYTCAAACATCATYAAYAAYCAYCA & $1 \times$ & $50^{\circ} \mathrm{C}$ & $30 \mathrm{~min}$ & 1001 & $17084-18084$ & Modified from \\
\hline & YH30-R1m & GAGATGATYTGRTKCTTRAAYTTCTGRAA & & $94^{\circ} \mathrm{C}$ & $2 \min$ & & & Wijegoonawardane \\
\hline & & & $35 \times$ & $94^{\circ} \mathrm{C}$ & $45 \mathrm{~s}$ & & & et al. (2008a) \\
\hline & & & & $55^{\circ} \mathrm{C}$ & $45 \mathrm{~s}$ & & & \\
\hline & & & & $68^{\circ} \mathrm{C}$ & $60 \mathrm{~s}$ & & & \\
\hline & & & $1 \times$ & $68^{\circ} \mathrm{C}$ & $7 \mathrm{~min}$ & & & \\
\hline $\mathrm{nPCR}$ & YH31-F2m & CTCARATCCATGCMATYTGGGARTCHTC & $1 \times$ & $95^{\circ} \mathrm{C}$ & $15 \mathrm{~min}$ & 721 & $17277-17997$ & Modified from \\
\hline & YH31-R2m & AGT TTG GCR CGR ATR TTR GTR AGR AT & $35 \times$ & $94^{\circ} \mathrm{C}$ & $45 \mathrm{~s}$ & & & Wijegoonawardane \\
\hline & & & & $55^{\circ} \mathrm{C}$ & $45 \mathrm{~s}$ & & & et al. (2008a) \\
\hline & & & & $72^{\circ} \mathrm{C}$ & $60 \mathrm{~s}$ & & & \\
\hline & & & $1 \times$ & $72^{\circ} \mathrm{C}$ & $7 \min$ & & & \\
\hline
\end{tabular}


Table 2. Performance of OIE (World Organisation for Animal Health) YHV diagnostic RT-PCR and RT-nPCR assays on RNA extracted from Penaeus monodon samples. GAV: gill-associated virus; (+/-) positive/negative results, respectively

\begin{tabular}{|lcccc|}
\hline PCR assay & Target & Sample & Sample & Sample \\
& & 1 & 2 & 3 \\
\hline OIE YHV Protocol 1 RT-PCR & YHV1 & - & - & - \\
OIE YHV Protocol 2 RT-PCR & YHV1/GAV & + & + & + \\
OIE YHV Protocol 2 GAV nPCR & GAV & - & - & + \\
OIE YHV Protocol 2 YHV1 nPCR & YHV1 & - & - & - \\
OIE YHV Protocol 3 RT-PCR & YHV1-YHV6 & + & + & + \\
OIE YHV Protocol 3 nPCR & YHV1-YHV6 & + & + & + \\
\hline
\end{tabular}

Table 3. Nucleotide identity of the Sample 1 OIE YHV Protocol 2 RT-PCR, ORF1b sequence (KP738160), in comparison to available GenBank sequences

\begin{tabular}{|lclc|}
\hline Genotype & $\begin{array}{c}\text { GenBank } \\
\text { accession no. }\end{array}$ & Country & $\begin{array}{c}\text { Percent } \\
\text { identity }\end{array}$ \\
\hline YHV1 & FJ848673 & Thailand & 80.4 \\
YHV1 & FJ848674 & Thailand & 81.2 \\
YHV1 & EU487200 & Thailand & 81.0 \\
YHV1 & FJ848675 & Thailand & 79.8 \\
YHV1 & AF148846 & Thailand & 80.4 \\
YHV1 & EU977578 & Thailand & 80.4 \\
YHV1 & FJ627274 & Thailand & 79.7 \\
GAV & AF227196 & Australia & 77.6 \\
YHV5 & EU170438 & Thailand & 79.7 \\
Unassigned & KF278563 & China & 78.1 \\
\hline
\end{tabular}

pure growth of Vibrio harveyi, and the presence of a bacterial septicaemia was supported by the observation of multiple melanised granulomas, haemocyte aggregations and haemocyte nests (data not shown).

\section{Molecular analysis}

Three OIE YHV PCR protocols were performed to determine whether a yellow-head-complex virus was associated with the mortality. The OIE YHV Protocol 1 RT-PCR, specific for YHV1, was negative for all samples (Table 2). The OIE YHV Protocol 2 RTPCR (Protocol 2) yielded an amplicon of $794 \mathrm{bp}$ for all samples, but the YHV nPCR, specific for YHV1, was negative. The GAV nPCR produced a faint amplicon of $359 \mathrm{bp}$, indicative of GAV, in Sample 3 (Table 2). The OIE YHV
Protocol 3 RT-nPCR (Protocol 3), capable of amplifying all 6 YHV genotypes, generated amplicons for all 3 samples in both the RT-PCR and nPCR of approximately 360 and $150 \mathrm{bp}$, respectively (Table 2).

The sequence of Sample 1 obtained from the Protocol 2 RT-PCR amplicon (748 bp primer trimmed, KP738160), yielded 10 BLAST hits with complete coverage for the amplified ORF1b region (Table 3). Seven Thai YHV1 sequences available in GenBank were most similar to the Sample 1 sequence, but only shared $81.2 \%$ or less identity. In contrast, the Australian GAV sequence (AF227196) was the least similar at $77.6 \%$ identity. A yellow-head-complex virus of a new genotype from China (KF278563) and the YHV5 sequence from Thailand (EU170438) also shared $<80 \%$ identity. However, due to the lack of publicly available YHV3, YHV4 and YHV6 sequences in this ORF1b region, it was not possible to determine the YHV genotype detected.

The Protocol 3 RT-PCR amplicons (307 bp primer trimmed) for all 3 samples were sequenced (KP738161, KP738162 and KP738163) and found to be identical except for 1 nucleotide difference in Sample 1. Again, the highest identity (87.6\%) to either sample was with YHV1 when comparing the same ORF1b region for representatives of YHV Genotypes 1 to 6 (Table 4). The YHV4 genotype had the lowest identity $(80.1 \%)$ when compared to Sample 1. A sequence for the new Chinese YHV genotype (Liu et al. 2014) for the ORF1b region amplified by Protocol 3 RT-PCR was not available from GenBank. Based on the low sequence identity in 2 distinct ORF1b regions amplified by the Protocol 2 RT-PCR and Protocol 3 RT-PCR, the Queensland hatchery samples appeared to contain a previously unknown YHV genotype.
Table 4. Percent nucleotide identity of the OIE YHV Protocol 3 RT-PCR, ORF1b region, for Samples 1 (KP738161), 2 (KP738162) and 3 (KP738163), compared to representative strains of YHV Genotypes 1 to 6

\begin{tabular}{|lccccc|}
\hline $\begin{array}{l}\text { GenBank } \\
\text { accession } \\
\text { no. }\end{array}$ & Strain & Country & Genotype & \multicolumn{2}{c|}{$\begin{array}{c}\text { Percent identity } \\
\text { Sample }\end{array}$} \\
\hline EU784982 & THA-03-D1 & Thailand & YHV1 & 87.3 & 87.6 \\
EU785029 & AUS-00-H2 & Australia & GAV & 81.4 & 81.8 \\
EU784996 & VNM-02-H278 & Vietnam & YHV3 & 81.8 & 82.1 \\
EU785005 & IND-02-H5 & India & YHV4 & 80.1 & 80.5 \\
EU785003 & MYS-03-H4 & Malaysia & YHV5 & 86.0 & 86.3 \\
EU785036 & MOZ-04-H11 & Mozambique & YHV6 & 81.1 & 81.4 \\
& & & & & \\
\hline
\end{tabular}


Table 5. Nucleotide (upper right) and amino acid (lower left) pair-wise comparison of the YH30m/31m RT-nPCR, ORF1b region of YHV7 (Sample 2-KP738164) with representative YHV1 (EU784982), GAV (EU785029), YHV3 (EU784996), YHV4 (EU785005), YHV5 (EU785003) and YHV6 (EU785036) sequences

\begin{tabular}{|lccccccc|}
\hline & YHV1 & GAV & YHV3 & YHV4 & YHV5 & YHV6 & YHV7 \\
\hline YHV1 & - & 81.8 & 82.8 & 80.8 & 84.3 & 81.7 & 85.5 \\
GAV & 94.5 & - & 93.2 & 82.1 & 84.1 & 96.5 & 82.9 \\
YHV3 & 95.0 & 97.7 & - & 82.0 & 84.7 & 92.9 & 83.1 \\
YHV4 & 91.4 & 93.2 & 93.2 & - & 84.7 & 82.5 & 81.7 \\
YHV5 & 94.5 & 96.8 & 95.9 & 94.5 & - & 84.3 & 85.9 \\
YHV6 & 94.5 & 100.0 & 97.7 & 93.2 & 96.8 & - & 83.1 \\
YHV7 & 93.2 & 95.0 & 93.6 & 90.9 & 93.6 & 95.0 & - \\
\hline
\end{tabular}

To further characterise this novel YHV genotype, a longer region of ORF1b encompassing the Protocol 3 RT-PCR region was amplified using the YH30m/31m RT-nPCR. The $670 \mathrm{bp}$ primer-trimmed sequence from Sample 2 (KP738164) was compared with ORF1b sequences from 69 strains representing each of the yellow-head-complex virus genotypes. Sample 2 clustered phylogenetically most closely with the YHV1 genotype cluster (Fig. 1), although identity was approximately $86 \%$ with both YHV1 and YHV5 (Table 5). Translation of the ORF1b sequences revealed the novel genotype had 95\% identity with GAV (YHV2) and YHV6 and only a 93.2\% identity to YHV1 (Table 5).

\section{DISCUSSION}

A new yellow-head-complex genotype, YHV7, has been identified based on low nucleotide identity $(<88 \%)$ and phylogenetic comparisons of the ORF1b region with the 6 previously characterised YHV genotypes. Since the discovery of GAV, this work describes the only other detection of a yellow-headcomplex virus in Australia. The YHV7 virus was detected in diseased Penaeus monodon broodstock, but the source could be shrimp from either the Joseph Bonaparte Gulf or the Queensland hatchery. The roles of YHV7 and the bacterial infection contributing to the poor health and mortality observed in P. monodon are unknown.

The Protocol 2 RT-nPCR is a sensitive multiplex nested RT-PCR designed to differentiate YHV1 from GAV (YHV2), but a lack of specificity in the nested step has previously been identified with this protocol (OIE 2014). The detection of an RT-PCR amplicon and no nested PCR amplicons, as was the case for YHV7, has occurred previously with a YHV1b/YHV5
EU785009 VNM-02-H6 EU785013 VNM-01-H77 EU785008 VNM-02-H64 81 - EU785039 VNM-01-H65 - EU785031 AUS-00-HL5 EU784989 AUS-97-MCMS2 EU785029 AUS-00-H2 E EU784992 THA-04-H20 EU785024 THA-03-HB3 EU785027 THA-04-HK EU785030 AUS-00-HL4

- EU785028 AUS-00-HL11 EU785025. THA-03-HG 99 EU785021 THA-03-HA 99 LU785022 THA-03-HB 95 AF227196 GAVcg EU785026 AUS-96-Ref EU784980 AUS-97-MCMS-1 80 EU785038 AUS-97-MCMS3

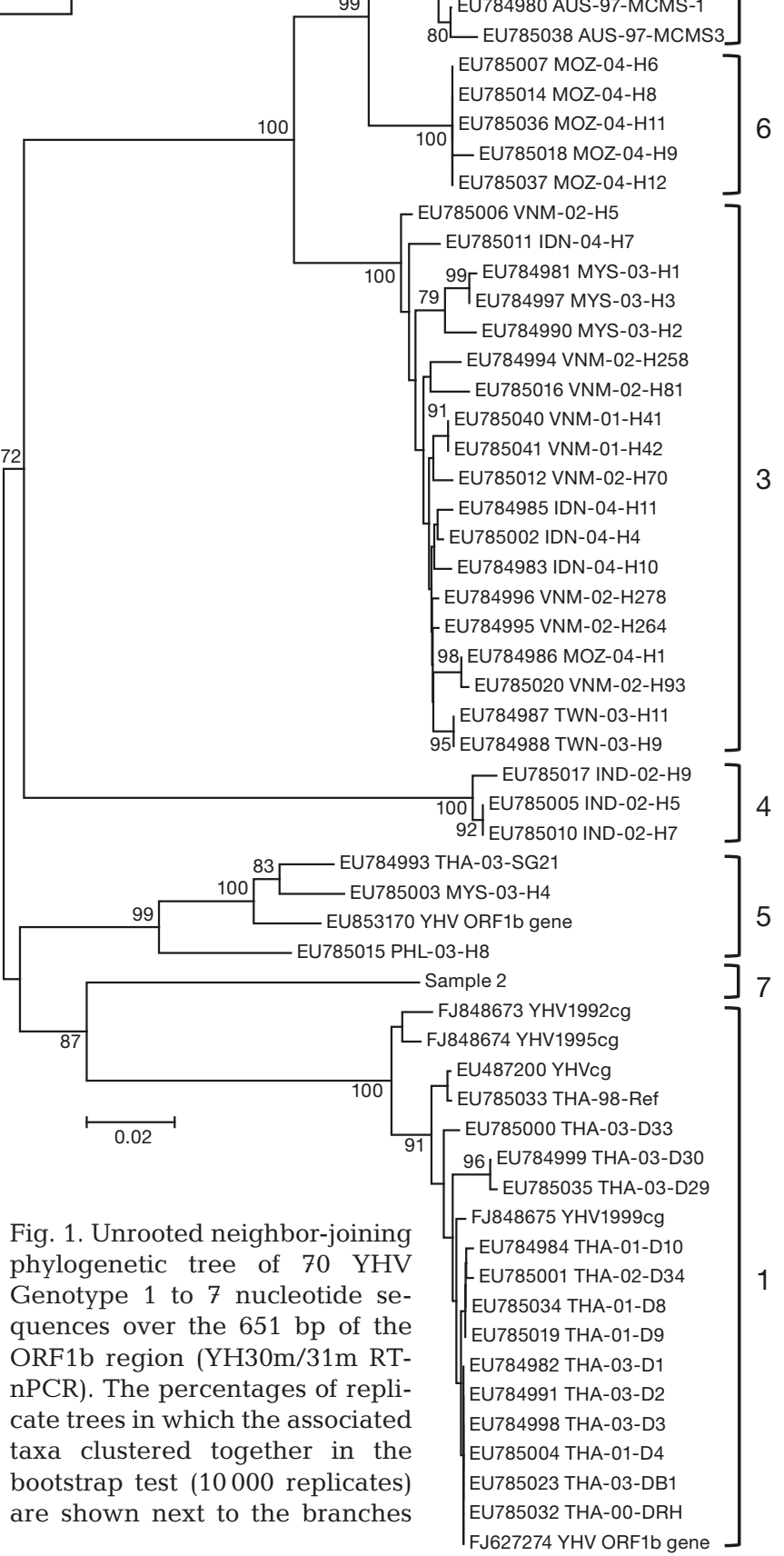


recombinant virus (Gangnonngiw et al. 2009). A similar result has also been observed for an, as yet, unassigned yellow-head-complex virus detected in several provinces of China (Liu et al. 2014). However, our analysis demonstrated that YHV7 was distinct from the Chinese isolate (Table 3). In contrast, the Protocol 3 RT-nPCR was able to generate amplicons for YHV7 in both PCR steps, expanding the number of genotypes detected by this consensus assay to 7 .

To assist the Australian shrimp aquaculture industry in assessing what risks YHV7 might pose, research is currently underway to determine its prevalence in wild $P$. monodon in regions where broodstock are commonly captured. Transmission trials to determine the pathogenicity of YHV7 in P. monodon are also required. However, to avoid confounding factors, GAV-free $P$. monodon would need to be sourced for such experiments. Research is also underway to sequence additional YHV7 isolates to enable greater understanding of the relationship of YHV7 with the previously characterised okavirus isolates.

Acknowledgements. The authors thank the QDAFF staff for specimen collection and processing, and the CSIRO AAHL Sequencing Laboratory.

\section{LITERATURE CITED}

Callinan RB, Jiang L, Smith PT, Soowannayan C (2003) Fatal, virus-associated peripheral neuropathy and retinopathy in farmed Penaeus monodon in eastern Australia. I. Pathology. Dis Aquat Org 53:181-193

Castro-Longoria R, Quintero-Arredondo N, Grijalv-Chon JM, Ramos-Paredes J (2008) Detection of the yellowhead virus (YHV) in wild blue shrimp, Penaeus stylirostris, from the Gulf of California and its experimental transmission to the Pacific white shrimp, Penaeus vannamei. J Fish Dis 31:953-956

> Chantanachookin C, Boonyaratpalin S, Kasornchandra J, Direkbusarakom S and others (1993) Histology and ultrastructure reveal a new granulosis-like virus in Penaeus monodon affected by yellow head disease. Dis Aquat Org 17:145-157

> Cowley JA, Dimmock CM, Wongteerasupaya C, Boonsaeng V, Panyim S, Walker PJ (1999) Yellow head virus from Thailand and gill-associated virus from Australia are closely related but distinct prawn viruses. Dis Aquat Org 36:153-157

> Cowley JA, Dimmock CM, Spann KM, Walker PJ (2000) Detection of Australian gill-associated virus (GAV) and lymphoid organ virus (LOV) of Penaeus monodon by RTnested PCR. Dis Aquat Org 39:159-167

Cowley JA, Cadogan LC, Wongteerasupaya C, Hodgson RAJ, Boonsaeng V, Walker PJ (2004) Multiplex RTnested PCR differentiation of gill-associated virus (Australia) from yellow head virus (Thailand) of Penaeus

Editorial responsibility: Catherine Collins,

Aberdeen, UK monodon. J Virol Methods 117:49-59

> Gangnonngiw W, Anantasomboon G, Sang-Oum W, Sriurairatana S, Sritunyalucksana K, Flegel TW (2009) Nonvirulence of a recombinant shrimp nidovirus is associated with its non-structural gene sequence and not a large structural gene deletion. Virology 385:161-168

Lightner DV (1996) A handbook of shrimp pathology and diagnostic procedures for diseases of cultured penaeid shrimp. World Aquaculture Society, Baton Rouge, LA

Liu Q, Huang J, Yang HL, Yang B and others (2014) Detection of a new genotype of yellow-head virus in farmed shrimp suspicious of EMS/AHPNS infection. Oceanol Limnol Sin 45:703-709

Lo CF, Leu JH, Ho CH, Chen CH and others (1996) Detection of baculovirus associated with white spot syndrome (WSBV) in penaeid shrimps using polymerase chain reaction. Dis Aquat Org 25:133-141

Munro J, Callinan R, Owens L (2011) Gill-associated virus and its association with decreased production of Penaeus monodon in Australian prawn farms. J Fish Dis 34:13-20

OIE (World Organisation for Animal Health) (2014) Yellowhead disease. In: Manual of diagnostic tests for aquatic animals. OIE, Paris. Available at: www.oie.int/internationalstandard-setting/aquatic-manual/access-online/

Preston N, Coman G, Cowley J, Herbst N, Moore N (2010) Black tiger breeding program yields record shrimp harvests in Australia. Glob Aquacult Advoca 13(5):95

Senapin S, Thaowbut Y, Gangnonngiw W, Chuchird N, Sriurairatana S, Flegel TW (2010) Impact of yellow head virus outbreaks in the whiteleg shrimp, Penaeus vannamei (Boone), in Thailand. J Fish Dis 33:421-430

> Sittidilokratna N, Chotwiwatthanakun C, Wijegoonawardane PKM, Unajak S and others (2009) A virulent isolate of yellow head nidovirus contains a deformed envelope glycoprotein gp116. Virology 384:192-200

Spann KM, Cowley JA, Walker PJ, Lester RJG (1997) A yellow-head-like virus from Penaeus monodon cultured in Australia. Dis Aquat Org 31:169-179

Tamura K, Peterson D, Peterson N, Stecher G, Nei M, Kumar S (2011) MEGA5: molecular evolutionary genetics analysis using maximum likelihood, evolutionary, distance, and maximum parsimony methods. Mol Biol Evol 28: 2731-2739

Walker PJ, Bonami JR, Boonsaeng V, Chang PS and others (2005) Family Roniviridae. In: Fauquet CM, Mayo MA, Maniloff J, Desselerger U, Ball LA (eds) Virus taxonomy: 8th report of the international committee on taxonomy of viruses. Elsevier \& Academic Press, San Diego, CA, p 975-979

Wijegoonawardane PKM, Cowley JA, Phan T, Hodgson RAJ, Nielsen L, Kiatpathomchai W, Walker PJ (2008a) Genetic diversity in the yellow head nidovirus complex. Virology 380:213-225

Wijegoonawardane PKM, Cowley JA, Walker PJ (2008b) Consensus RT-nested PCR detection of yellow head complex genotypes in penaeid shrimp. J Virol Methods 153: 168-175

> Wongteerasupaya C, Tongchuea W, Boonsaeng V, Panyim S, Tassanakajon A, Withyachumnarnkul B, Flegel TW (1997) Detection of yellow head virus (YHV) of Penaeus monodon by RT-PCR amplification. Dis Aquat Org 31: 181-186

Submitted: February 9, 2015; Accepted: June 11, 2015 Proofs received from author(s): August 11, 2015 